\title{
Pengaruh Meniran Dosis Bertingkat Terhadap Ekspresi IGF-1 Dan Ketebalan Endometrium Pada Mencit Betina Model Endometriosis
}

\author{
Eka Deviany Widyawaty ${ }^{1}$, Hendy Hendarto ${ }^{2}$, Widjiati $^{3}$ \\ ${ }^{1}$ Mahasiswa Magister Ilmu Kesehatan Reproduksi, Fakultas Kedokteran, \\ Universitas Airlangga Surabaya \\ ${ }^{2}$ Departemen Obstetri dan Ginekologi, Fakultas Kedokteran, Universitas Airlangga, \\ RSUD Dr. Soetomo \\ ${ }^{3}$ Departemen Embriologi Veteriner, Fakultas Kedokteran Hewan, Universitas Airlangga \\ e-mail : ekadeviany49@gmail.com
}

\begin{abstract}
Abstrak
Endometriosis menyebabkan 10-15\% dari nyeri panggul dan infertilitas pada wanita usia reproduksi. Walaupun endometriosis dapat mempengaruhi infertilitas, tetapi mekanisme dari hal tersebut sampai sekarang masih belum diketahui secara pasti. Penelitian ini bertujuan untuk mengetahui pengaruh pemberian ekstrak etanol herba meniran (Phyllanthus niruri L.) dosis bertingkat terhadap ekspresi IGF-1 dan ketebalan endometrium pada mencit (Mus musculus) betina model endometriosis. Sampel penelitian ini adalah mencit (Mus Musculus) betina model endometriosis. Pada hari ke-15, Kelompok Kontrol (K1) diberi Na CMC 0,5\% dan Kelompok perlakuan (K2), (K3), (K4) diberi ekstrak herba etanol herba meniran dosis $14 \mathrm{mg} / 20 \mathrm{gBB}, 28 \mathrm{mg} / 20 \mathrm{gBB}$, dan $56 \mathrm{mg} / 20 \mathrm{gBB}$. Pada hari ke-29 dilakukan pembedahan dan pengambilan sampel endometrium dengan pemeriksaan imunohistokia pada ekspresi IGF-1 dan pewarnaan Hematoxylin-eosin pada ketebalan endometrium. Uji statistik menunjukkan bahwa ada pengaruh pemberian ekstrak etanol herba meniran (Phyllantinus niruri L.) dosis bertingkat terhadap ekspresi IGF-1 dengan nilai $p=0,041<0,05$ dan ada pengaruh pemberian ekstrak etanol herba meniran (Phyllantinus niruri L.) dosis bertingkat terhadap ketebalan endometrium dengan nilai $p=0,021<0,05$. Pemberian ekstrak etanol herba meniran (Phyllanthus niruri L.) dosis bertingkat pada mencit (Mus musculus) betina model endometriosis dapat meningkatkan ekspresi IGF-1 dan ketebalan endometriosis.
\end{abstract}

Kata Kunci : Ekstrak etanol herba meniran, ekspresi IGF-1, ketebalan endometrium 


\begin{abstract}
Endometriosis causes $10-15 \%$ of pelvic pain and infertility in women of reproductive age. Although endometriosis can affect infertility, the mechanism of this is still unknown. The research purpose to determine the effect of graded doses herbal ethanol extract of meniran (Phyllantinus niruri L.) on expression of IGF-1 and endometrial thickness female mice (Mus musculus) model of endometriosis. The sample of this study were mice (Mus Musculus) female endometriosis models. On the $15^{\text {th }}$ day, the Control Group (K1) was given Na CMC 0.5\% and the treatment group (K2), (K3), (K4) was given a herbal ethanol extract of meniran dose of 14 $\mathrm{mg} / 20 \mathrm{gBB}, 28 \mathrm{mg} / 20 \mathrm{gBB}$ and $56 \mathrm{mg} / 20 \mathrm{gBB}$. On day 29, surgery and endometrial sampling were performed with immunohistochemistry on expression of IGF-1 and colouring Hematoxylin-eosin on endometrial thickness. Statistical test showed that there was an effect of multivariate herbal ethanol extract of meniran (Phyllantinus niruri L.) on expression of $I G F-1$ with $p$ value $=0.041<0.05$ and there was an effect herbal ethanol extract of meniran (Phyllantinus niruri L.) dose level of endometrial thickness with a value of $p=0.021<0.05$. Herbal ethanol extract of meniran (Phyllantinus niruri L.) dosage increased in female mice (Mus Musculus) model of endometriosis can increase expression of IGF-1 and endometrial thickness.
\end{abstract}

Keywords : herbal ethanol extract of Meniran, expression of IGF-1, endometrial thickness

\section{PENDAHULUAN}

Endometriosis merupakan kelainan endometrium yang berada diluar rongga uterus. Endometriosis mempengaruhi 6\% hingga $10 \%$ wanita usia reproduksi dari semua etnis dan kelompok sosial (Fassbender et al., 2013). Endometriosis menyebabkan $10-15 \%$ dari nyeri panggul dan infertilitas pada wanita usia reproduksi. Beberapa penelitian menunjukkan bahwa 25-50\% wanita dengan infertilitas adalah penderita endometriosis dan 30-50\% wanita dengan endometriosis dengan infertilitas. Walaupun endometriosis dapat mempengaruhi infertilitas, tetapi mekanisme dari hal tersebut sampai sekarang masih belum diketahui secara pasti (Ghazal et al., 2015). Angka prevalensi penderita endometriosis sulit diketahui, tetapi diduga berkisar antara $2-10 \%$ pada wanita usia subur (Hendarto, 2015).

Sekitar 6-15\% wanita usia reproduksi dipengaruhi oleh endometriosis meskipun kejadian sebenarnya tidak diketahui karena beberapa pasien tetap asimtomatik. Gejala klasik termasuk dismenore, nyeri panggul kronis, dispareunia, perdarahan uterus tidak teratur, dan infertilitas. Dalam beberapa kasus, penyakit ini dapat melemahkan dan mengerahkan dampak dramatis pada kesehatan dan kualitas hidup. Faktor pertumbuhan seperti insulin, termasuk insulin, IGF-1, dan IGF-12, memainkan peran penting dalam mediasi dan modulasi pertumbuhan dan diferensiasi hormon seks pada sel endometrium. Insulin diberikan fungsinya melalui interaksi dengan reseptor insulin (INSR), sedangkan tindakan baik IGF-1 dan IGF-12 terutama dimediasi oleh reseptor IGF-1 (IGF1R). Pada penelitian Baker tahun 1996 disebutkan bahwa tikus betina dengan defisiensi IGF-1 mengalami infertilitas dan terdapat adanya hipoplasia uterus. IGF-1 dan IGF1R diekspresikan pada epitelium dan stroma endometrium. Tingkat ekspresi mereka berfluktuasi selama siklus menstruasi dengan tingkat ekspresi tertinggi berada di fase proliferatif akhir. Ekspresi mereka diatur, setidaknya sebagian oleh steroid ovarium, terutama 17-beta estradiol (E2). Estrogen yang tinggi mengakibatkan penurunan ekspresi H19 secara signifikan pada endometrium eutopik wanita dengan endometriosis dibandingkan dengan kontrol normal. Penurunan H19 dapat meningkatkan aktivitas let-7 dan hal tersebut menghambat ekspresi IGF1R pada tingkat pasca- 
transkripsional, sehingga berkontribusi untuk mengurangi proliferasi sel-sel stroma endometrium. Gangguan yang terjadi jalur regulasi H19 / Let-7 / IGF1R mengakibatkan adanya gangguan persiapan dan reseptif endometrium untuk kehamilan pada wanita dengan endometriosis (Ghazal et al., 2015).

Endometriosis merupakan penyakit yang progresif yang kemungkinan memerluan terapi dalam jangka panjang (Anas dkk., 2014). Angka kekambuhan setelah terapi endometriosis cukup tinggi, yaitu sekitar 35\% pada endometriosis ringan dan 74\% pada endometriosis berat (Speroff, 2005).

Secara fisiologis, tubuh manusia menghasilkan antioksidan (antioksidan endogen) yang berfungsi untuk melawan radikal-radikal bebas dan molekul berbahaya lainnya. Namun, jika radikal bebas yang menyerang tubuh berlebihan, tentunya diperlukan pula antioksidan dari luar (antioksidan eksogen) untuk melawannya. Antioksidan eksogen tersebut dapat berasal dari berbagai sumber termasuk dari alam, salah satunya adalah tumbuhan meniran (Phyllanthus niruri L.).

Meniran (Phyllanthus niruri L.) merupakan tumbuhan liar yang tersebar di seluruh Indonesia. Meniran mengandung kaya akan senyawa lignan antara lain filantin, hipofilantin, senyawa flavonoid : quersetrin, isoquersetrin, astragalin, dan rutin. Meniran ini memiliki aktivitas antiinflamasi, disebutkan bahwa ekstrak etanol meniran (Phyllantinus niruri L.) memberikan aktivitas penghambatan enzim xantin oksidase paling tinggi yaitu pada konsentrasi $31,25 \mathrm{mg} / \mathrm{ml}$ dengan aktivitas penghambatan 97,65 \% (Kemenkes RI, 2012). Ekstrak etanol herba meniran (Phyllantinus niruri L.) ini disebutkan dapat memberikan aktivitas antiinflamasi yang signifikan pada tikus dengan dosis 1000 $\mathrm{mg} / \mathrm{kgBB}, \quad 2000 \mathrm{mg} / \mathrm{kgBB}$ dan 4000 $\mathrm{mg} / \mathrm{kgBB}$ (Ligouri, 2016).

Mencit yang digunakan dalam penelitian ini adalah mencit strain Balb/C, hal itu dikarenakan rentang hidup yang panjang, dan relatif tahan terhadap perlakuan yang diinduksi. Mencit mempunyai homologi yang tinggi dengan manusia, kemudahan pemeliharaan dan penanganan, dan tingkat reproduksi yang tinggi, membuat tikus terutama model yang cocok untuk penelitian berorientasi manusia. Genom tikus laboratorium telah diurutkan dan banyak gen tikus memiliki homolog manusia.

Berdasarkan latar belakang di atas maka peneliti tertarik untuk mengetahui Pengaruh Pemberian Ekstrak Etanol Herba Meniran (Phyllanthus niruri L.) dosis bertingkat terhadap Ekspresi IGF-1 dan Tebal Endometrium pada Mencit (Mus musculus) Betina Model Endometriosis.

\subsection{Konsep Dasar Endometriosis}

Endometriosis adalah jaringan mirip endometrium diluar kavum uteri yang menginduksi reaksi inflamasi kronis. Endometriosis biasanya ditemukan di ovarium, peritoneum, panggul, septum rektovagina, ureter, maupun vesika urinaria (Norwitz, 2010).

Angka prevalensi endometriosis pelvis pada wanita yaitu sebesar 6-10\%. Beberapa penderita terdiagnosa secara kebetulan pada saat operasi ginekologi dengan berbagai indikasi. Sebanyak 5-15\% ditemukan pada saat laparoskopi pada wanita usia subur, 33\% ditemukan pada wanita dengan nyeri pelvis kronis, dan 30$45 \%$ ditemukan pada wanita infertil. Didapatkan angka kejadian endometriosis sebesar $60-80 \%$ pada penderita dismenore, $30-50 \%$ penderita nyeri panggul kronis, 24$40 \%$ penderita dispareuni, $10-20 \%$ penderita dengan siklus menstruasi yang kacau dan $30-40 \%$ pada pasangan suami istri yang infertil (Samsulhadi, 2002).

Patogenesis endometriosis hingga saat ini belum diketahui secara pasti. Ada beberapa teori yang menjadi penyebab endometriosis, antara lain sebagai berikut :

1. Teori Retrograde Menstruation dan Teori Implantasi

Teori ini diperkenalkan oleh Sampson tahun 1927, endometriosis terjadi karena adanya refluks aliran darah menstruasi melalui tuba falofii masuk ke rongga peritoneum. Saat menstruasi, darah keluar melalui tuba falofii masuk ke rongga abdomen, lalu terjadi implantasi pada peritoneum dan 
berkembang menjadi lesi endometriosis (Burney et al., 2012).

Refluks aliran darah menstruasi terjadi pada sekitar $80 \%$ wanita, namun hanya $0,5-5 \%$ yang menjadi endometriosis. Hal ini berhubungan dengan lingkungan pelvik yang dapat menerima implantasi endometrium dan kemudia berkembang menjadi endometriosis. Sel-sel endometrium yang diperoleh dari cairan peritoneum saat menstruasi dapat tumbuh dalam kultur jaringan dan dapat menempelserta berpenetrasi pada wanita dengan menarche yang lebih dini, siklus menstruasi yang lebih pendek atau menoragia (Speroff et al., 2005).

2. Teori Ceolomic Metaplasia dan Teori Induksi

Meyer tahun 1942 menyebutkan bahwa sel peritoneum, permukaan ovarium dan duktus Muller berasal dari prekusor embriologi yang sama yaitu epitel coelomic. Teori ini didukung oleh beberapa kejadian endometriosis pada wanita yang belum mengalami menstruasi dan juga pada wanita yang baru mengalami beberapa kali menstruasi (Speroff, 2005).

Menurut teori ini, pembentukan endometrioma dalam endometriosis ovarium atau rektovaginal disebabkan oleh metaplasia epitel coelomic. Selain itu, endometriosi juga dapat ditemukan pula pada pleura yang berasal dari epitel coelomic sama seperti peritoneum dan duktus Mullerian (Baldi et al., 2008). Rangsangan imunologi atau zat biokimia secara endogen maupun eksogen dapat menginduksi epitel coelomic yang terdiferensiasi menjadi sel endometrium dikenal dengan teori induksi (Sourial et al., 2014).

3. Teori Metastasis Vaskular dan Limfatik

Endometriosis yang berada jauh dari rongga pelvis diduga berasal dari penyebaran melalui pembuluh darah dan aliran limfe. Teori ini dikenal dengan teori Halban, dan dibuktikan lewat pemeriksaan histologi dimana ditemukan sel endometrium pada pembuluh darah pelvis. Teori ini dibuktikan juga dalam pengamatan aliran limfatik uterus ke ovarium dengan menggunakan bahan kontras, dimana ditemukan sel endometrium dalam kelenjar limfe tersebut. Sehingga hal inilah yang dapat menjelaskan kejadian endometriosis yang jauh dari rongga pelvis, diantaranya paruparu, pluera, perikardium dan sebagainya (Norwitz et al., 2010).

Teori Halban menduga bahwa terjadinya endometriosis pada lokasi yang jauh oleh karena penyebaran sel endometrium melalui pembuluh darah atau penyebaran limfatik. Teori ini menjelaskan lesi endometriosis yang terjadi pada tempat di luar pelvis (misalnya otak dan paru-paru), tetapi tidak dapat dijelaskan mengapa lesi lebih sering terjadi di pelvis yang diduga berkaitan dengan gravitasi (Hapsari, 2017).

4. Teori Imunologi

Sel endometrium dalam cairan peritoneum ditemukan pada $98 \%$ wanita masa reproduksi. Lebih dari $90 \%$ wanita mampu membersihkan sel endometrium ektopik dan pada 1-7\% wanita yang tidak mampu membersihkan sel ektopik yang akhirnya berkembang menjadi lesi endometriosis. Ketidakmampuan tersebut mungkin disebabkan banyaknya refluks aliran darah menstruasi melebihi kapasitas pembersihan sistem imun atau terjadi defek pada sistem imun (Kyama $e t$ al., 2003).

Sel-sel sistem imun pada peritoneum pada umumnya dapat mengaktivasi faktor inflamasi dan faktor pertumbuhan yang berperan terhdap implantasi sel endometrium menjadi endometriosis. Perubahan imunitas seluler juga diduga berperan dalam patogenesis terjadinya endometriosis, dimana imunitas yang tidak adekuat diperitoneum diduga sebagai penyebab berkembangnya endometriosis. Salah satu sel yang dianggap mengalami perubahan fungsi adalah makrofag, dimana makrofag yang seharusnya aktif memfagosit sel ektopik, berubah menjadi kurang aktif (Hapsari, 2017).

Sel endometriosis dapat bertahan dari pengaruh sitokin proapoptosis yang disekresi sel-sel imun pada peritoneum. 
Berkurangnya kemampuan apoptosis ini diduga karena sel endometriosis tidak mampu memberi sinyal proapotosis sehingga terhindar dari proses apoptosis. Hal ini terkait adanya pengaruh ekspresi gen anti apoptosis yang meningkat seperti Bcl-2 (B-cell lymphoma) dan Bcl$\mathrm{XL}$ serta mengurangi ekspresi gen proapotosis yaitu Bax (Bcl-2 associated $V$ protein). Demikian pula, apabila terjadi aktivasi Nuclear Factor Kappa B (NF$\mathrm{kB})$, maka sel endometriosis akan bertahan dan tetap berproliferasi (Nasu $e t$ al., 2007).

5. Teori Stem Cell

Stem cell adalah sel yang tidak/belum terspesialisasi dan mempunyai sifat mampu berdiferensiasi menjadi sel lain dan mampu meregenerasi diri sendiri (self renewal). Stem cell diketahui juga terdapat pada lapisan basalis endometrium dan berperan pada regenerasi endometrium, antara lain : setiap bulan setelah menstruasi, pasca persalinan dan post kuretase. Saat ini, sel klonogenik yang merupakan representasi populasi stem cell pada endometrium manusia telah diidentifikasi dan diduga kuat berkaitan dengan tumbuhnya formasi jaringan endometrium ektopik (Hendarto, 2015).

Eksistensi stem cell endometrium pluripoten dan kontribusi bone marrow sebagai sumber lain stem cell endometrium, menciptakan teori kombinasi patogenesis endometriosis. Stem cell endometrium yang lepas melalui saluran tuba falopii saat menstruasi dan juga stem cell dari bone marrow yang bersirkulasi, bertanggung jawab terhadap terjadinya implan endometriosis pada rongga peritoneum dan ikut berperan pada patogenesis endometriosis (Hendarto, 2015).

Penyebab pembentukan lesi endometriosis adalah sebagai berikut :

1. Implantasi endometrium

Endometrium yang berasal dari kavum uteri bisa mencapai lingkungan ektopik atau keluar dari kavum uteri dengan berbagai cara dan dapat tumbuh di tempat yang baru. Cara yang banyak disebut adalah secara refluks atau retrograde melalui tuba fallopii saat menstruasi. Cara lain dapat terjadi saat dilakukan seksio sesarea ke jaringan luka (insisi) atau saat persalinan ke perineum (robekan episiotomi). Selain itu, perpindahan sel endometrium juga diduga dapat melalui aliran darah dan limfe ke organ yang jauh, seperti paruparu. Namun endometrium yang berada dijaringan lain tidak otomatis tumbuh menjadi lesi endometriosis yang berada dijaringan lain tidak otomatis tumbuh menjadi lesi endometriosis (Hendarto, 2015).

Walaupun kejadian retrograde terjadi pada $76-90 \%$ wanita, kejadian endometriosis hanya terjadi pada sekitar $10-15 \%$.tentu ada keadaan tertentu yang mempermudah atau memungkinkan endometrium ini untuk hidup dan berkembang pada jaringan lain. Prosesnya diterangkan berdasarkan temuan perbedaan kadar, respon biologis hormon seks, growth factors, sitokin dan enzim antara penderita endometriosis dan non-endometriosis di endometrium, endometrium ektopik/jaringan endometriosis (Hendarto, 2015).

2. Faktor angiogenesis

Untuk mengadakan implantasi dan tumbuh, endometrium ektopik harus mempunyai suplai darah yang cukup. Implan endometriosis tampak dikelilingi vaskularisasi yang meningkat, demikian pula pada endometriosis diluar pelvis, sering ditemukan ditempat yang vaskularisasinya baik. Lapisan endometrium wanita yang akan menjadi endometriosis sudah mempunyai fenotip angiogenik yang aktif. Beberapa penelitian menunjukkan bahwa cairan peritoneum penderita endometriosis mengandung bahan untuk aktivitas angiogenik yang lebih tinggi dibanding wanita normal, diantaranya : Basic Fibroblast Growth Factor ( FGF- $\alpha, F G F$ $\beta)$, IL-6, IL-8, Platelet Derived Endothelial Cell Growth Factor (PDECGF), Vascular Endothelial Growth Factor (VEGF), TGF- $\alpha, T G F-\beta, T N F-\alpha$, dan mRNA VEGF (Gonzales et al., 2012). 
Vascular Endothelial Growth Factor merupakan mediator spesifik untuk terjadinya angiogenesis berupa pembentukan lumen vaskuler dan pengendali permeabilitas vaskuler. Induksi VEGF distimulasi oleh faktor pertumbuhan, sitokin dan keadaan hipoksia. Faktor pertumbuhan ini merangsang proliferasi sel endotel dan bertindak sebagai kemoatraktan bagi monosit (Gonzales et al., 2012).

3. Perlengketan pada endometriosis

Bahan biokimia yang disekresi lesi endometriosis atau sel sekitarnya dapat berperan untuk terjadinya fibrosis dan perlengketan. Transforming Growth Factor $-\beta$ yang terkait dengan berbagai pembentukan perlengketan intraperitoneum meningkat di cairan peritoneum penderita endometriosis. Growth factor yang ditemukan di jaringan endometrium dan cairan peritoneum penderita endometriosis diduga berperan dalam proliferasi jaringan endometriosis. Selian itu, pada endometriosis juga ditemukan bahwa jumlah apoptosis pada endometrium dan epitel endometriosis menurun. Peningkatan proliferasi dan menurunnya apoptosis menyebabkan sel bertambah banyak dan bertahan lebih lama sehingga memudahkan terjadinya lesi endometriosis (Gupta et al., 2008).

Awal perlengketan diduga karena peran hyaluronic acid yang diekspresikan sel mesotel peritoneum dan reseptornya CD44 yang diekspresikan sel epitel dan stroma endometrium. Laminin dan fibronektin, dua golongan glikoprotein untuk perlengketan (adhesi), memegang peran penting dalam melekatnya sel epitel ke selaput dasar, dan sel stroma ke matriks interstisiel. Distribusi laminin dan fibronektin dan reseptornya identik di endometriosis dan endometrium, kecuali reseptor fibronektin. Ekspresi sitokin (IL-1 $\beta$,IL-6 dan TNF- $\alpha$ ) dan aktivitasnya di endometrium penderita endometriosis yang meningkat juga memudahkan terjadinya adhesi fragmen ini (Azinar, 2003).
Gold standard diagnosis endometriosis adalah melalui visualisasi dengan laparoskoi, baik dengan atau tanpa konfirmasi histologi. Namun, keluhan penderita juga dapat menjadi pertanda awal mengenali suatu endometriosis. Terdapat dua masalah yang sering menjadi keluhan penderita endometriosis, yaitu nyeri dan infertilitas. Keluhan yang sering dikeluhkan pasien, antara lain nyeri haid, nyeri panggul, nyeri senggama, keluhan intestinal siklik, kelelahan dan infertilitas. Keluhan nyeri tersebut biasanya berhubungan dengan siklus haid, tergantung pada lokasi lesi endmetriosis, tetapi tidak tergantung pada stadium endometriosis (Hendarto, 2015).

Pemeriksaan fisik seperti inspekulo dan vaginal touche juga dapat mendeteksi adanya deep infiltrating endometriosis. Pemeriksaan pencitraan seperti transvaginal ultrasonografi atau MRI, dapat menemukan adanya massa ginekologi seperti endometrioma atau adenomyosis. Beberapa pemeriksaan pertanda serum dapat digunakan sebagai alat diagnostik, begitu pula pemeriksaan $\mathrm{Ca}-125$ dan kombinasi beberapa pemeriksaan sitokin (Samsulhadi, 2002; Falconer et al., 2005).

Untuk menggambarkan luasnya patologi endometriosis, American Fertility Society (AFS) tahun 1979 menerapkan sistem skoring pada temuan kasus endometriosis dan menggolongkannya ke dalam suatu klasifikasi endometriosis. Klasifikasi endometriosis berdasarkan American Fertility Revised Classification of Endometriosis, dibagi menjadi 4 stadium

Endometriosis merupakan penyakit yang progresif yang kemungkinan memerluan terapi dalam jangka panjang (Anas dkk., 2014). Angka kekambuhan setelah terapi endometriosis cukup tinggi, yaitu sekitar 35\% pada endometriosis ringan dan $74 \%$ pada endometriosis berat (Speroff, 2005).

Terapi endometriosis memiliki dua tujuan, yaitu : untuk menghilangkan rasa sakit, mengobati infertilitas, atau keduanya. Agen yang telah lama digunakan untuk mengobati endometriosis, antara lain : agen untuk menekan fungsi ovarium, membatasi pertumbuhan dan aktivitas endometriosis, dan pengobatan untuk mengurangi rasa sakit 
yang terkait dengan penyakit ini, termasuk: nonsteroid anti-inflammation drugs (NSAIDs), androgen, progestagen, agonis GnRH, dan kontrasepsi hormonal. Terapi medis sebagian besar lebih unggul daripada plasebo untuk pengobatan nyeri terkait endometriosis (Bulun et al., 2009).

Agen yang paling banyak digunakan adalah agonis GnRH dan kontrasepsi oral. US Food and Drug Administration (FDA) telah resmi menyetujui agonis GnRH dan danazol untuk pengobatan endometriosis. Akan tetapi, pemberian terapi hormonal dan analgetika dalam jangka panjang dapat menyebabkan keadaan hipoestrogen sehingga menghambat folikulogenesis dan ovulasi (Hendarto, 2015; Guyton, 2012). Adanya efek samping penekanaan ovulasi ini menyebabkan pemberian terapi hormonal untuk mengurangi nyeri dan progresivitas endometriosis, tidak dapat dilakukan bersamaan dengan penanganan infertilitas. Oleh karena itu, penggunaan teknologi reproduksi berbantu, termasuk hiperstimulasi ovarium terkontrol dan inseminasi intrauterin, atau fertilisasi in vitro dan transfer embrio merupakan tindakan yang menguntungkan dalam mengatasi infertilitas (Nasu et al., 2007; Anas dkk., 2014).

Pada uji coba secara acak kolaboratif di Kanada, 341 wanita infertil dengan endometriosis stadium I atau II secara dilakukan laparoskopi diagnostik atau pengobatan bedah. Peserta ditindaklanjuti selama 36 minggu pasca operasi dan sampai 20 minggu kehamilan. Tingkat kehamilan secara signifikan lebih tinggi pada wanita yang dilakukan pembedahan sebesar $30,7 \%$ : $17,7 \%$ (Guidice et al., 2010).

\subsection{Konsep Dasar Insulin-like Growth Factor-1 (IGF-1)}

Insulin-like Growth Factor-1 (IGF-1) adalah hormon yang sama dengan struktur molekul insulin. IGF-1 memainkan peran penting dalam pertumbuhan masa kanakkanak dan terus memiliki efek anabolik pada orang dewasa. IGF-1 terdiri dari 70 asam amino dalam rantai tunggal dengan tiga disulfida jembatan intramolekul. IGF-1 memiliki berat molekul 7649 dalton (Keating, 2008).
IGF-1 adalah mediator utama dari efek hormon pertumbuhan (GH). Hormon pertumbuhan dibuat dalam kelenjar hipofisis anterior, dilepaskan ke dalam aliran darah, dan kemudian merangsang hati untuk memproduksi IGF-1. IGF-1 kemudian merangsang pertumbuhan tubuh sistemik, dan memiliki efek pertumbuhan mempromosikan di hampir setiap sel dalam tubuh, terutama otot rangka, tulang rawan, tulang, hati, ginjal, saraf, kulit, sel hematopoietik, dan paru-paru (Merritt et al., 2015).

Wanita dengan endometriosis telah mengubah ekspresi gen di endometrium eutopik sehingga menjadi tidak subur. Endometriosis menyebabkan adhesi dan jaringan parut pada anatomi panggul, yang dapat merusak pelepasan oosit atau menyebabkan sumbatan tuba. Estradiol menstimulasi ekspresi H19 di endometrium. Ketika kadar H19 naik, ia bertindak sebagai spons untuk mengurangi let-7, sehingga dapat menstimulasi IGF1R. Peningkatan kadar protein IGF1R menyebabkan peningkatan pensinyalan IGF1 dengan titik akhir biologis peningkatan proliferasi sel-sel stroma endometrium. Pada wanita endometriosis, terjadi perubahan ekspresi H19 pada endometrium eutopik, yang menyebabkan peningkatan bioavailabilitas let-7. Hal ini memungkinkan peningkatan penghambatan dari IGF1R dan dengan demikian menurunkan pensinyalan IGF-1, yang akhirnya menyebabkan penurunan proliferasi sel stroma. Perubahan dalam regulasi proliferasi sel endometrium H19 / Let-7 / IGF1R ini dapat mewakili mekanisme potensial untuk infertilitas pada wanita dengan endometriosis. H19 merupakan sebuah RNA noncoding panjang yang biasanya diekspresikan dalam endometrium eutopik yang memainkan peran dalam mengatur pertumbuhan sel stroma endometrium melalui pengaturan microRNA let-7 dan reseptor fase 1 yang berhadapan dengan target pertumbuhan insulin 1 (IGF1R). Pada penelitian Ghazal tahun 2015 disebutkan bahwa ekspresi H19 menurun pada endometrium eutopik wanita dengan endometriosis bila dibandingkan dengan wanita tanpa endometriosis. H19 bertindak sebagai "spons molekuler" untuk 
mengurangi let-7, sehingga mengurangi bioavailabilitasnya. Penurunan ekspresi H19 menyebabkan peningkatan aktivitas let-7, yang bertindak untuk menghambat ekspresi IGF1R, menghasilkan penurunan proliferasi sel stroma. Pengaturan ekspresi IGF1R pada sel-sel stroma endometrium pada wanita dengan endometriosis, dapat berdampak pada persiapan dan penerimaan endometrium mereka terhadap kehamilan (Ghazal et al., 2015).

\subsection{Konsep Dasar Ekstrak Etanol Herba Meniran}

Meniran (Phyllantinus niruri L.) merupakan tanaman liar (gulma), banyak terdapat di ladang, tanah berbatu, hutan yang lembab. Tumbuh tersebar hampir di seluruh Indonesia pada ketinggian antara 1-1000 m dpi. Tumbuhan liar di tempat terbuka pada tanah gembur yang mengandung pasir, di ladang, di tepi sungai, dan dipantai. Tinggi meniran (Phyllantinus niruri L.) dapat mencapai 0,8 meter, berwarna hijau letak cabang tersebar, daun tunggal, letak berseling pada ujung cabang dengan posisi mendatar terhadap batang pokok. Helaian daun berbentuk elip pendek sampai lonjong, panjang 0,5-2 cm, lebar 0,25-0,5 cm, pangkal membulat sampai tumpul, ujung membulat, tumpul atau runcing, warna hijau pucat. Mahkota bunga berbentuk bulat telur terbalik, panjang 0,75-1 mm, warna hijau muda bergaris merah (Kemenkes RI, 2012).

Akar dan daun meniran (Phyllantinus niruri L.) kaya akan senyawa lignan antara lain filantin, hipofilantin, senyawa flavonoid : quersetrin, isoquersetrin, astragalin, dan rutin. Minyak dari biji mengandung beberapa asam lemak, yaitu asam risinoleat, asam linoleat, dan asam linolenat. Kandungan senyawa lain pada herba meniran diantaranya nirantin, nirtetralin, nirurin, nirurinetrin, norsekurinin, filantenol, filnirutin, dan nirtetrin. Selain itu meniran mengandung juga kalium, damar dan tanin (Kemenkes RI, 2012).

Efek etanol meniran memberikan aktivitas penghambatan enzim xantin oksidase paling tinggi pada konsentrasi $31,25 \mathrm{mg} / \mathrm{ml}$ dengan aktivitas penghambatan $97,65 \%$ sedangkan aktivitas penghambatan fraksin-heksana, etilasetat, dan fraksi air masing-masing 49, 79, 61, 32 dan 90,43\%. Hasil penapisan fitokimia ekstrak etanol menunjukkan adanya golongan senyawa flavonoid dan polifenol. Pada pengobatan tradisional Indonesia, meniran (Phyllantinus niruri L.) digunakan sebagai peluruh batu ginjal atau batu kandung kemih. Pada pemberian ekstrak meniran dosis 15,15 $\mathrm{mg} / \mathrm{kgBB}$ pada tikus jantan yang diinduksi asam glikolat, secara signifikan mengurangi berat batu ginjal dan pada dosis 15,15 $\mathrm{mg} / \mathrm{kgBB}$ telah memberikan efek diuretik. Ekstrak meniran dengan dosis 45, 90 dan $180 \mathrm{mg} / \mathrm{kgBB}$ dapat berkhasiat sebagai antihepatotoksik pada tikus putih yang telah diinduksi parasetamol dengan parameter yang diamati adalah aktivitas enzim SGOT dan SGPT hewan coba. Ekstrak air meniran dapat menghambat DNA polimerase endogen virus hepatitis B dan ikatan pada HbsAg secara in vitro. Uji klinis meniran menunjukkan aktivitas sebagai imunomodulator, berperan membuat sistem kekebalan tubuh lebih aktif menjalankan tugasnya sekaligus meningkatkan sistem imun tubuh, sehingga meningkatkan kekebalan atau daya tahan tubuh terhadap serangan virus, bakteri, atau mikroba. Kandungan utama meniran (Phyllantinus niruri L.) yang berupa flavonoid dan glikosida flavonoid yang menghambat kerja enzim xantin oksidase dan superoksidase sehingga digunakan dalam antiinflamasi (Kemenkes RI, 2012).

\subsection{Konsep Dasar Mencit (Mus Musculus)}

Mencit merupakan hewan coba yang sering digunakan dalam penelitian dikarenakan mencit murah dan mudah untuk ditangani, rentang hidup yang singkat, mudah beradaptasi dan tingkat reproduksinya cepat hal itu memungkinkan kita untuk meneliti pada semua tahap siklus hidup. Selain itu mencit ini mempunyai kesamaan dengan manusia mulai dari kesamaan DNA, gen, sistem reproduksi, sistem syaraf, penyakit bahkan kecemasan, hal tersebut menjadi alasan mencit dapat sering digunakan hewan coba penelitian (Susan, 2016).

Mencit digolongkan kedalam ordo Rodorensia (hewan pengerat) dan famii 
Muridae. Ordo Rodorensia merupakan ordo dengan jumlah spesies tersebar dari kelas mammalia, yaitu mencapai $40 \%$ dari 5.000 spesies mammalia. Mencit memiliki kemampuan menyesuaikan diri yang baik dengan lingkungannya, baik saat cuaca dingin maupun panas. Ada klasifikasi mencit (Mus Musculus) adalah sebagai berikut :

$\begin{array}{ll}\text { Kingdom } & \text { : Animalia } \\ \text { Filum } & \text { : Chordata } \\ \text { Subfilum } & \text { : Vertebrata } \\ \text { Kelas } & \text { : Mammalia } \\ \text { Ordo } & \text { : Rodentia } \\ \text { Subordo } & \text { : Myoporpha } \\ \text { Famili } & : \text { Muridae } \\ \text { Subfamili } & \text { : Murinae } \\ \text { Genus } & : \text { Mus } \\ \text { Spesies } & \text { :Mus Musculus }\end{array}$

(Sumarsono, 2016)

Mencit sering digunakan dalam penelitian endometriosis dikarenakan rentang hidup yang panjang, dan relatif tahan terhadap perlakuan yang diinduksi. Mencit mempunyai homologi yang tinggi dengan manusia, kemudahan pemeliharaan dan penanganan, dan tingkat reproduksi yang tinggi, membuat tikus terutama model yang cocok untuk penelitian berorientasi manusia. Genom tikus laboratorium telah diurutkan dan banyak gen tikus memiliki homolog manusia.

Untuk membuat mencit menjadi model endometriosis, sesuai dengan teori patogenesis endometriosis, maka perlu dilakukan penekanan sistem imun tubuh agar jaringan endometrium yang diinduksikan bisa berkembang. Cara penekanan sistem imun ini dilakukan dengan injeksi siklosporin A yang telah terbukti mampu menurunkan jumlah limfosit sehingga jaringan endometrium manusia yang disuntikkan ke dalam rongga peritoneum mencit dapat tumbuh menjadi endometriosis yang dibuktikan dengan pemeriksaan patologi anatomi (Permana dkk., 2016).

\section{METODE PENELITIAN}

Jenis penelitian yang digunakan dalam penelitian ini adalah penelitian eksperimental dengan rancangan penelitian true experiment. Pendekatan dalam penelitian ini menggunakan Randomized Subject, Posttest only control group design.
Besar sampel yang digunakan dalam penelitian ini adalah enam mencit (Mus musculus) setiap kelompok yang terdiri dari 1 kelompok kontrol dan 3 kelompok perlakuan.

Mencit sebelum dilakukan penelitian diaklimatisasi selama 7 hari, kemudian dibuat menjadi model endometriosis dengan cara memberikan hari-1 memberikan injeksi Siklosporin A secara intramuskular sebanyak 0,2 ml, kemudian memberikan injeksi jaringan endometrium sebanyak 0,1 $\mathrm{ml}$ secara intraperitoneal pada setiap mencit yang dijadikan sampel. Pada hari ke-5 mencit diinjeksi estrogen (ethynil estradiol) sebanyak $20.000 \mu$ dan pada hari ke-15 diharapkan mencit telah menjadi model endometriosis. Setelah itu mencit diberikan perlakuan selama 14 hari pada kelompok kontrol (K1) diberi Na CMC 0,5\% dan pada kelompok perlakuan $(\mathrm{K} 2, \mathrm{~K} 3, \mathrm{~K} 4)$ diberi ekstrak etanol herba meniran dosis $14 \mathrm{mg} / 20 \mathrm{gBB}, \quad 28 \mathrm{mg} / 20 \mathrm{gBB}$ dan 56 $\mathrm{mg} / 20 \mathrm{gBB}$. Kemudian pada hari ke 29, mencit dikorbankan pada diperiksa ekspresi IGF-1 dengan menggunakan imunohistokia sedangkan ketabalan endometrium dengan metode pewarnaan (Haematoxylin-eosin).

Data penelitian ini dicatat dalam formulir pengambilan data. Analisa data menggunakan software SPSS (Software Package for Social Science). Dilakukan uji normalitas menggunakan uji Kolmogorof Smirnov. Bila data berdistribusi normal dilanjutkan dengan uji Anova One Way. Bila data tidak berdistribusi normal akan dilanjutkan dengan uji Mann-Whitney. Untuk mengetahui adanya pengaruh masingmasing perlakuan dilakukan Uji $\mathrm{T}$. Tingkat kemaknaan yang dipergunakan dalam penelitian ini sebesar 0,05 .

\section{HASIL DAN PEMBAHASAN}

Insulin-like Growth Factor-1 (IGF-1) adalah hormon yang sama dengan struktur molekul insulin. IGF-1 adalah mediator utama dari efek hormon pertumbuhan (GH). Wanita dengan endometriosis telah mengubah ekspresi gen di endometrium eutopik sehingga menjadi tidak subur (Ghazal et al., 2015).

Ekspresi IGF-1 pada Kelompok K1, K2, K3 dan K4 dilihat dari epitelium, gland 
uterus dan stroma uterus dilakukan dengan metode imunohistokimia menggunakan mikroskop Eclipse E 100 pembesaran $400 \mathrm{x}$.

Tabel 4.1 Rerata dan simpangan baku peningkatan pemberian dosis ekstrak etanol herba meniran (Phyllanthus niruri L.) terhadap ekspresi IGF-1

\begin{tabular}{cccc}
\hline \multicolumn{4}{c}{ Ekspresi IGF-1 (Imunohistokimia) } \\
\hline $\mathrm{K} 1$ & $\mathrm{~K} 2$ & $\mathrm{~K} 3$ & $\mathrm{~K} 4$ \\
\hline $\mathbf{0 , 4} \pm \mathbf{0 , 2 6}$ & $\mathbf{1} \pm \mathbf{0 , 3 8 8}$ & $\mathbf{1 , 0 3} \pm \mathbf{0 , 2 9 6}$ & $\mathbf{1 , 4 4} \pm \mathbf{1 , 0 0 9}$ \\
\hline
\end{tabular}

Uji Anova One-Way Ekspresi IGF-1 pada mencit (Mus Musculus) betina model endometriosis dapat dilihat pada Tabel 4.2 Tabel 4.2 Uji Anova One-Way Ekspresi IGF-1

\begin{tabular}{lccc}
\hline & F Statistik & $\begin{array}{c}\text { p- } \\
\text { value }\end{array}$ & Signifikan \\
\hline Uji Anova & 3,311 & 0,041 & Signifikan \\
One-Way & & & \\
\hline
\end{tabular}

Berdasarkan pada tabel 4.2 menunjukkan bahwa hasil Uji Anova OneWay Ekspresi IGF-1 pada mencit (Mus Musculus) betina model endometriosis yang diberi ekstrak etanol herba meniran (Phyllanthus niruri L.) dosis bertingkat, diketahui nilai $\mathrm{p}=0,041$ dimana $\mathrm{p}<\alpha(0,05)$ maka dapat disimpulkan bahwa peningkatan pemberian dosis ekstrak etanol herba meniran (Phyllanthus niruri L.) pada mencit (Mus Musculus) betina model endometriosis dapat meningkatkan IGF-1.

Endometriosis menyebabkan adhesi dan jaringan parut pada anatomi panggul, yang dapat merusak pelepasan oosit atau menyebabkan sumbatan tuba. Estradiol menstimulasi ekspresi H19 di endometrium. Ketika kadar H19 naik, ia bertindak sebagai spons untuk mengurangi let-7, sehingga dapat menstimulasi IGF1R. Peningkatan kadar protein IGF1R menyebabkan peningkatan pensinyalan IGF1 dengan titik akhir biologis peningkatan proliferasi sel-sel stroma endometrium. Pada wanita endometriosis, terjadi perubahan ekspresi H19 pada endometrium eutopik, yang menyebabkan peningkatan bioavailabilitas let-7. Hal ini memungkinkan peningkatan penghambatan dari IGF1R dan dengan demikian menurunkan pensinyalan IGF-1, yang akhirnya menyebabkan penurunan proliferasi sel stroma. (Ghazal et al., 2015).
Meniran ini memiliki aktivitas antiinflamasi, disebutkan bahwa ekstrak etanol meniran (Phyllantinus niruri L.) memberikan aktivitas penghambatan enzim xantin oksidase paling tinggi yaitu pada konsentrasi $31,25 \mathrm{mg} / \mathrm{ml}$ dengan aktivitas penghambatan 97,65 \% (Kemenkes RI, 2012).

Penurunan ekspresi IGF-1 pada wanita dengan endometriosis, dapat berdampak pada persiapan dan penerimaan endometrium mereka terhadap kehamilan. Meniran yang mengandung flavonoid dapat meningkatkan ekspresi IGF-1 sebesar 33\% sehingga meniran dapat menjadi salah satu terapi herbal yang dapat diberikan pada penderita endometriosis.

Endometrium eutopik pada wanita dengan endometriosis memiliki beberapa perbedaan mendasar dibandingkan dengan eutopik endometrium pada wanita tanpa endometriosis. Perubahan struktur, proliferasi, komponen kekebalan tubuh, molekul adhesi, proteolitik enzim dan inhibitor, produksi steroid dan sitokin dan responsif, dan ekspresi gen dan produksi protein endometrium terjadi pada wanita dengan endometriosis (Sharpe-timms, 2001).

Heterogenitas dari epitel permukaan endometrium terdapat $77 \%$ wanita dengan endometriosis dan $16 \%$ dari kontrol tanpa endometriosis. Mitosis kelenjar dan stroma, sel vacuolated basal, dan rasio sel bersilia terhadap nonciliated berkurang secara signifikan pada kelompok endometriosis dibandingkan dengan kontrol. Studi observasi klinis menunjukkan ketebalan endometrium yang tidak adekuat pada wanita yang mengalami endometriosis superovulasi dan inseminasi intrauterin dibandingkan dengan wanita dengan diagnosis lain (Sharpe-timms, 2001).

Ketebalan endometrium mencit model endometriosis pada penelitian ini diukur dengan metode pewarnaan (Haematoxylineosin). Pengukuran ketebalan endometrium dilihat menggunakan Mikroskop Nikon Eclipse E100 dengan pembesaran 400X.

Tabel 4.3 Rerata dan simpangan baku peningkatan pemberian dosis ekstrak etanol herba meniran (Phyllanthus niruri L.) terhadap ketebalan endometrium 
Jurnal Biosains Pascasarjana Vol. 20 (2018) pp

(C) (2018) Sekolah Pascasarjana Universitas Airlangga, Indonesia

\begin{tabular}{lccc}
\hline \multicolumn{4}{c}{ Ketebalan endometrium (Hematoxylin-eosin) } \\
\hline $\mathrm{K} 1$ & $\mathrm{~K} 2$ & $\mathrm{~K} 3$ & $\mathrm{~K} 4$ \\
\hline $384,26 \pm$ & $407,07 \pm$ & $451,11 \pm$ & $561,69 \pm$ \\
112,18 & 80,78 & 101,14 & 87,35 \\
\hline Uji & Anova & One-Way & Ketebalan \\
Endometrium pada mencit (Mus & Musculus) \\
betina model endometriosis & dapat & dilihat \\
pada Tabel 4.4
\end{tabular}

Tabel 4.4 Uji Anova One-Way Ketebalan Endometrium

\begin{tabular}{lccc}
\hline & F Statistik & $\begin{array}{c}\text { p- } \\
\text { value }\end{array}$ & Signifikan \\
\hline $\begin{array}{l}\text { Uji Anova One- } \\
\text { Way }\end{array}$ & 4,033 & 0,021 & Signifikan \\
\hline
\end{tabular}

Berdasarkan pada tabel 5.12 menunjukkan bahwa hasil Uji Anova OneWay Ketebalan Endometrium pada mencit (Mus Musculus) betina model endometriosis yang diberi ekstrak etanol herba meniran (Phyllanthus niruri L.) dosis bertingkat, diketahui nilai $\mathrm{p}=0,021$ dimana $\mathrm{p}<\alpha(0,05)$ maka dapat disimpulkan bahwa peningkatan pemberian dosis ekstrak etanol herba meniran (Phyllanthus niruri L.) dosis bertingkat pada mencit (Mus Musculus) betina model endometriosis dapat meningkatkan Ketebalan Endometrium.

Penurunan ketebalan endometrium pada wanita dengan endometriosis, dapat berdampak pada gangguan persiapan dan penerimaan endometrium mereka terhadap kehamilan. Meniran yang mengandung flavonoid dapat meningkatkan ketebalan endometrium sebesar $26 \%$ sehingga meniran dapat menjadi salah satu terapi herbal yang dapat diberikan pada penderita endometriosis dengan infertilitas.

\section{KESIMPULAN DAN SARAN}

Pemberian ekstrak etanol herba meniran (Phyllanthus niruri L.) dosis $14 \mathrm{mg} / 20 \mathrm{gBB}$, $28 \mathrm{mg} / 20 \mathrm{gBB}$, dan $56 \mathrm{mg} / 20 \mathrm{gBB}$ pada mencit (Mus musculus) betina model endometriosis dapat meningkatkan ekspresi IGF-1 dan ketebalan endometrium.

Untuk penyempurnaan penelitian ini perlu dilakukan penelitian lanjutan untuk mengetahui pengaruh pengaruh ekstrak etanol herba meniran (Phyllantinus niruri L.) terhadap kadar ROS pada mencit (Mus Musculus) model endometriosis.

\section{DAFTAR PUSTAKA}

Amer, S. 2008. Endometriosis. Obstetric Gynaecology Reproductive Medicine. 18 : $126-133$.

Annas, JY., Hendarto, H., Widjiati. 2014. Khasiat Berbagai Dosis Suplementasi Kurkumin pada Progresivitas Endometriosis di Hewan Coba Mencit. Majalah Obstetri dan Ginekologi. 22 (3) : 118-125.

Azinar, LD. 2003. Patogenesis Endometriosis. Kumpulan Kuliah FER PPDS-Obstetri Ginekologi FK Unair Surabaya.

Baldi Alfonso, Campioni Mara, Peirtro G. Signorile. 2008. Endometriosis : Pathogenesis, diagnosis, therapy and association with cancer. ONCOLOGY REPORTS 19: 843-846. url : https://pdfs.semanticscholar.or $\mathrm{g} / 3 \mathrm{f} 5 \mathrm{f} / 9 \mathrm{c} 2 \mathrm{fd} 17 \mathrm{e} 255080 \mathrm{c} 78 \mathrm{~b} 3$ 12d00b196800a2b6a.pdf

Bulun, S. E. (2009). Endometriosis. The New England Journal of Medicine, 360(3), 268-79. http://doi.org/10.1056/NEJMr a0804690.

Burney, RO., and Giudice, LC. 2012. Pathogenesis and Endometriosis Breast Cancer Rev. 4:197-201. 68.

Chil TJ, Tan SL. 2001. Endometriosis Etiology.Pathogenesis, and Treatment. DrugsVolume 61 (12) : 1735 -1750.

Dmwowski WP, Braun DP. 2004. Immunology of Endometriosis. Best Practice and Research Clinical Obstetrics and Gynaecology Volume 18 (2) : 245-263.

Ghazal, S., McKinnon, B., Zhou, J., Mueller, M., Men, Yang, Taylor, H. S. (2015). H19 lncRNA alters stromal cell growth via IGF signaling in the endometrium of women with endometriosis. EMBO Molecular Medicine, 
7(8),

996-1003.

http://doi.org/10.15252/emm

m.201505245

Giudice L. C. (2010). Clinical practice. Endometriosis. $N$. Engl. J. Med. 362 2389-2398

Giudice, L.C. 2006. Endometrium in PCOS : implantation and predisposition to endocrine CA. Best practice and research clinical endocrinology and metabolism. 20 (2). 235-244.

Gonzalez Tirado I., Barrientos G., Tariverdian N., Arck P. C., Garc ia M. G., Klapp B. F., et al. (2012). Endometriosis research: animal models for the study of a complex disease.J. Reprod. Immunol. 86 141-147

Gupta, S., Goldberg, J.M., Aziz, N., Goldberg, E., Krajcir, N. and Agarwal, A. 2008. Pathogenic mechanism in endometriosisassociated infertility. Fertility Sterility $90: 247-257$.

Guyton Arthur C, John E Hall. 2012. Textbook of medical Physiology ed 12. Johanneshov : Philadelphia.

Hendarto H, Widjiati, Sudiana IK, Saadi A. 2009. Khasiat curcumin terhadap perubahan ekspresi VEGF, GDF-9, Hyaluronan untuk perbaikan terapi dan hasil fertilisasi pada endometriosis. Laporan penelitian unggulan strategis nasional 2009. Universitas Airlangga. Tidak diterbitkan.
Idikio H. A. 2010. Immunohistochemistry in diagnostic surgical pathology contributionof protein lifecycle, use of evidence-based methods and data normalization on interpretation of immunohistochemical stain. International journal of clinical and experimental pathology. 3 (2). 169.

Keating GM, (2008). Mecasermin. Bio Drugs, 22: 177.

Kementerian Kesehatan RI. 2012. Vademekum Tanaman Obat Saintifikasi Jamu Jilid 1 (Edisi Revisi). Jakarta : Badan Litbang Kesehatan.

Kusumawati, D. 2016. Bersahabat dengan hewan coba cetakan kedua. Gadjah Mada University Press. Yogyakarta.

Kyama Cleophas M, Sophie Debrock, Jason M Mwenda, Thomas M D'Hooghe. 2003. Potential involvement of the immune system in the development of endometriosis. DOI: 10.1186/1477-7827-1-123

Liguori, Alfonsus Vincent Sugiarto. 2016. Pengaruh Pemberian Ekstrak Meniran (Phyllantinus niruri L.) Dosis bertingkat terhadap gambaran mikroskopis gaster. http://eprints.undip.ac.id/5412 1/1/ALFONSUS _LIGUORI_VINCENT_2201 0113130170_Lap.KTI_Bab0. pdf

Merritt M, Strickler H, Einsten M, Yang H, Sherman M, Wentzensen N, BrouwerVisser J, Jose Cossio M, Whitney $\mathrm{KD}, \mathrm{Yu} \mathrm{H}$, Gunter M, Huang G. (2015). Insulin/ IGF and hormone axes in human endometrium and associations with endometrial cancer risk factor. Cancer Causes Control, 27:737-748.

Nasu K., Masakazu N, Ueda T, Akitoshi Y. 2007.Application of NFkB Inhibitor BAY 11-7085 for 
The Treatment Endmetriosis : An In vitro study. Am J Physiology Endocrinology Methabolism Volume 293 :16-23.

Norwitz E, Schorge J. 2010. Obstetric and gaenocology at a glance third edition. Wiley-Balckwell Publishing. Oxford.

Permana SV, Hendarto H, Soehartono DS. 2006. Pengaruh pemberian siklosporin A sebagai penurun jumlah limfosit serum terhadap terjadinya implan endometriosis pada mencit. Tesis. Departemen Obstetri dan Ginekologi Fakultas Kedokteran Universitas Airlangga. Tidak diterbitkan.

Samsulhadi. 2002. Endometriosis dari Biomolekuler sampai Masalah Klinik dalam Majalah Obstetri dan Ginekologi vol. 10 no. 1 : 43-50. SMF Obstetri dan Ginekologi Fak. Kedokteran Universitas Airlangga Surabaya, Juli 2002.

Sharpe-Timms, Kathy L. 2001. Endometrial anomalies in women with endometriosis. url : www.ncbi.nlm.nih.gov/pubme $\mathrm{d} / 11594534$

Sourial S, Nicola Tempest, Dharani K. Hapangama. 2014. Theories on the Pathogenesis of Endometriosis. Hindawi Publishing Corporation International Journal of Reproductive Medicine Volume 2014, Article ID 179515, 9 pages doi : http://dx.doi.org/10.1155/201 4/179515

Speroff, L. and Fritz, M.A. (2005) Clinical Gynecologic Endocrinology and Infertility. 7th Edition, Lippincott Williams \& Wilkins, Philadelphia.

Sumarsono, P. 2016. Potensi Antioksidan buah merah terhadap ekspresi caspase 9 dan jumlah sel tropoblas mencit bunting sebelum terpapar plumbum.
Tesis. Fakultas Kedokteran Hewan Universitas Airlangga. Tidak diterbitkan.

Wulandari Lisa Purbawaning, Budi Santoso, Bambang Purwanto. 2017. Kadar Malondialdehid Tikus Model Sindroma Ovarium Polikistik Dengan Daun Kelor (Moringa Oleifera). Jurnal Biosains Pascasarjana Vol 19 No. 3. doi : http://dx.doi.org/10.20473/bsn . v19i3.7575 